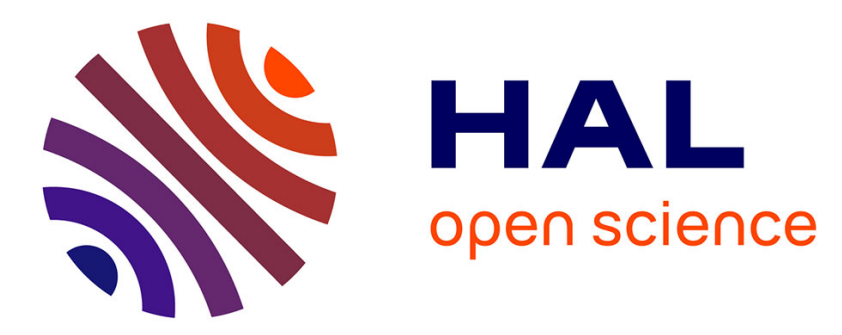

\title{
Seasonal changes in phosphatase activities in Toulon Bay (France)
}

Gérard Bogé, Natacha Jean, Jean-Louis Jamet, Dominique Jamet, Simone Richard

\section{- To cite this version:}

Gérard Bogé, Natacha Jean, Jean-Louis Jamet, Dominique Jamet, Simone Richard. Seasonal changes in phosphatase activities in Toulon Bay (France). Marine Environmental Research, 2006, 61 (1), pp.1 - 18. 10.1016/j.marenvres.2005.03.002 . hal-01893688

\section{HAL Id: hal-01893688 https://hal.science/hal-01893688}

Submitted on 1 Jun 2021

HAL is a multi-disciplinary open access archive for the deposit and dissemination of scientific research documents, whether they are published or not. The documents may come from teaching and research institutions in France or abroad, or from public or private research centers.
L'archive ouverte pluridisciplinaire HAL, est destinée au dépôt et à la diffusion de documents scientifiques de niveau recherche, publiés ou non, émanant des établissements d'enseignement et de recherche français ou étrangers, des laboratoires publics ou privés. 


\title{
Seasonal changes in phosphatase activities in Toulon Bay (France)
}

\author{
Gérard Boge a , Natacha Jean ${ }^{\mathrm{b}}$, Jean-Louis Jamet ${ }^{\mathrm{a}, *}$, \\ Dominique Jamet ${ }^{\text {a }}$, Simone Richard ${ }^{\text {a }}$ \\ ${ }^{a}$ Université du Sud Toulon-Var, Equipe de Biologie des Milieux Aquatiques, PROTEE, EA, BP 20132, \\ F-83957 La Garde cedex, France \\ ${ }^{\mathrm{b}}$ CNAM/Intechmer E. A 3202 "Environnements Marins Naturels et Contrôlés”, Digue de Collignon, \\ BP 324, 50103 Cherbourg cedex, France
}

\begin{abstract}
We studied the characteristics of the phosphatase activity ( $\mathrm{Km}$ and Vmax) in total seawater and in particulate material of the three main plankton classes $(0.25-5,5-90$ and $>90 \mu \mathrm{m})$ in a coastal marine ecosystem of Toulon Bay (French Mediterranean Sea). The measurement of the hydrolysis of sodium paranitrophenylphosphate (pNPP), a substrate of phosphatase, revealed low and high affinity components in unfiltered seawater and in particulate matter. In unfiltered seawater, the low affinity activity was predominant from October to March during phytoplankton development. The high affinity activity dominated from April to June and was significantly correlated with the bacterial abundances. The phosphatase behaviour in the particulate material differs from that in the unfiltered seawater. The activity of the three particulate classes was generally much lower than that of unfiltered seawater, particularly the low affinity activity. The $>90 \mu \mathrm{m}$ size fraction consisted in greater part of zooplankton. In this size class, the activity (nmol $\mathrm{l}^{-1} \mathrm{~h}^{-1}$ ) of the low affinity component was predominant from May to August, when the abundance of the larvae of copepods (copepodites) was highest. Its high specific activity (Activity/Protein concentration as $\mathrm{nmol}^{-1} \mathrm{~h}^{-1} \mu \mathrm{g}^{-1}$ ) was particularly elevated during this period. The 5-90 $\mu \mathrm{m}$ fraction consisted of phytoplankton cells, especially Dinoflagellates. Between September and January, the activity $\left(\mathrm{nmol} 1^{-1} \mathrm{~h}^{-1}\right)$ of this size class
\end{abstract}

\footnotetext{
Corresponding author.

E-mail address: jamet@univ-tln.fr (J.-L. Jamet).
} 
was mostly supported by the low affinity component. The specific activity (nmol $\mathrm{l}^{-1} \mathrm{~h}^{-1} \mu \mathrm{g}^{-1}$ ) of the high affinity component was highest in June and August. No significant correlation was found between phosphatase activities and chlorophyll $a$ or total cell abundance. In return temporary relationships with specific taxa exist in particular with Ceratium spp., Gymnodinium spp. and Protoperidinium spp. The contribution of the $0.25-5 \mu \mathrm{m}$ size class exceeded rarely $20 \%$ of the total particulate activity. Between June and August, high specific activities $\left(\right.$ nmol $\mathrm{l}^{-1} \mathrm{~h}^{-1} \mu \mathrm{g}^{-1}$ ) were observed for its high affinity component. In autumn, strong rainfall increased the phosphate and nitrate concentrations and led to a drop in salinity, which probably explains the low phosphatase activities $\left(\mathrm{nmol}^{-1} \mathrm{~h}^{-1}\right)$ and cell densities observed during this period.

Keywords: Marine plankton; Phosphatase; Particulate material; Eutrophication

\section{Introduction}

The Mediterranean Sea is one of the most oligotrophic seas in the world. However, anthropic activities, eutrophication and climatic changes are modifying its natural biological equilibrium considerably (Bethoux \& Copin-Montegut, 1988). This situation is particularly alarming in closed and semi-closed areas, where exchanges with the outside are reduced (Barth \& Fegan, 1990). This is the case of Toulon Bay, where we have been studying the ecology of plankton for several years. Phosphorus and nitrogen are two of the principal nutrients responsible for the development of plankton. In coastal waters, phosphorus esters contribute greatly to the growth of phytoplankton and bacteria (Benitez-Nelson, 2000; Huang \& Hong, 1999). These organisms produce enzymes, such as alkaline phosphatase and nucleotidase that hydrolyse dissolved organic phosphorus and make it possible for phytoplankton and bacterioplankton to grow despite the absence of dissolved inorganic phosphorus (Ammerman \& Azam, 1991; Hoppe, 2003; Jansson, Olsson, \& Pettersson, 1988). These enzymes have been well characterised in limnetic environments but have been less studied in seawater.

The aims of this study were to measure the phosphatase activity of seawater in Toulon Bay and to analyse the contribution of zooplankton, phytoplankton and bacteria to this enzyme production. Several authors have suggested that bacteria or phytoplankton are responsible for alkaline phosphatase activity (Boon, 1994; Siuda, 1984; Thingstad, Zweifel, \& Rassoulzadegan, 1998), whereas others believe that zooplankton species make a substantial contribution (Gambin, Bogé, \& Jamet, 1999). Thus, we considered three different plankton size classes (0.25-5, 5-90 and $>90 \mu \mathrm{m})$. The total activity in seawater was measured, as were the activities of the three size classes in relation to the abundances of the zooplankton, phytoplankton and bacteria communities. The use of a wide range of substrate concentrations made it possible to calculate the $\mathrm{Km}$ and Vmax values of low and high affinity activities. 


\section{Materials and methods}

\subsection{Study site}

Toulon (Lat. $43^{\circ} 05^{\prime} \mathrm{N}$ and Long. $6^{\circ} 00^{\prime} \mathrm{E}$ ) is located on the French N.W. Mediterranean coast (Fig. 1). Its seaport handles military, commercial and tourist traffic. Toulon Bay is divided into two areas by a breakwater: the western basin, also called Little Bay (maximum $23 \mathrm{~m}$ depth), is semi-enclosed; and the eastern basin, called Large Bay, is open to the sea. According to IFREMER, Little Bay is contaminated by chemical pollutants such as organic compounds (polychlorinated biphenyls, antifouling paints), heavy metals $(\mathrm{Hg}, \mathrm{Zn}, \mathrm{Pb}$ and $\mathrm{Cu}$ ) and occasionally by toxic plankton species such as Alexandrium and Dinophysis spp. (Belin \& Raffin, 1998; IFREMER, 1993). Little Bay contains also higher levels of chlorophyll $a$, higher abundance of zooplankton, and lower zooplankton diversity with a single dominant species (Cyclopoida, Oithona nana) than Large Bay (Jamet, Bogé, Richard, Geneys, \& Jamet, 2001; Richard \& Jamet, 2001). Phosphate and nitrate concentrations were episodically elevated in Little Bay, in particular after rainy periods with annual means of $133 \mathrm{nM}$ (min-max: 49-462 $\mathrm{nM}$ ) for orthophosphate and of $9 \mu \mathrm{M}(1.5$ 30) for nitrates (Table 1). In Large Bay the mean phosphate and nitrate concentrations were $97 \mathrm{nM}(59-168)$ and $5.5 \mu \mathrm{M}$ (2.0-19.7), respectively. For chlorophyll $a$ the annual means were in Little Bay: $2.43 \mu \mathrm{g}^{-1}(0.76-4.81)$ and in Large Bay: $0.4 \mu \mathrm{g} 1^{-1}$ $(0.1-1)$.

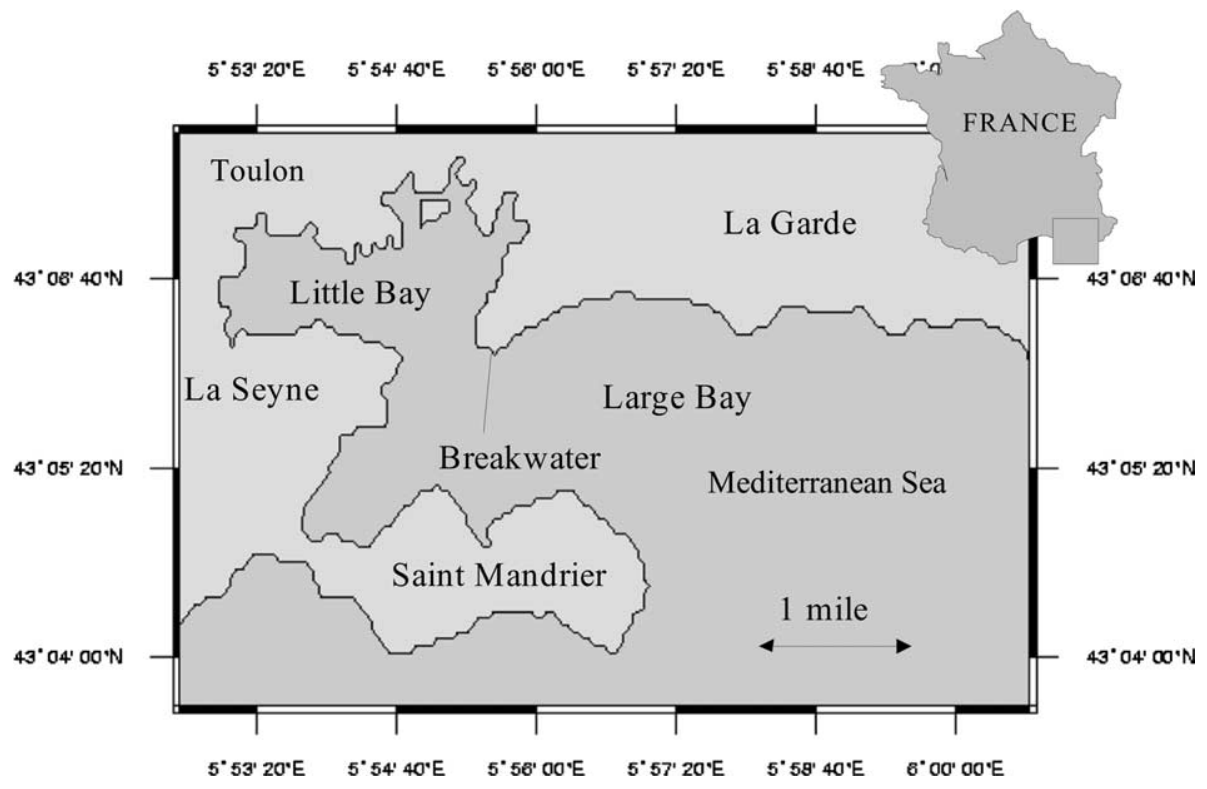

Fig. 1. Study site. 
Table 1

Abiotic parameters $\left(\mathrm{PO}_{4}^{3-}\right.$ concentrations in $\mathrm{nM}, \mathrm{NO}_{3}^{-}$concentrations in $\mu \mathrm{M}$ and salinity in $\left.\mathrm{g}^{-1}\right)$

\begin{tabular}{lrcc}
\hline & $\mathrm{PO}_{4}^{3-}$ & $\mathrm{NO}_{3}^{-}$ & Salinity \\
\hline September & 84 & 22 & 37.3 \\
October & 348 & 30 & 29 \\
November & 126 & 5 & 35.5 \\
December & 49 & 28 & 35.3 \\
January & 69 & 5 & 36.2 \\
February & 124 & 6 & 38 \\
March & 61 & 1.5 & 38.1 \\
April & 74 & 1.6 & 37.9 \\
May & 462 & 2.2 & 37.8 \\
June & 147 & 3.1 & 37.9 \\
July & 52 & 2.9 & 38 \\
August & 79 & 5.2 & 38.1 \\
September & 49 & 2.1 & 38.3 \\
\hline
\end{tabular}

\subsection{Field sampling}

Samples were collected monthly from September 1999 to September 2000 between 9.30 and 11.00 a.m. in the middle of the Little Bay. For the determinations of enzyme activity, chlorophyll, phosphate, nitrate and protein concentrations and for phytoplankton and bacteria counting, seawater was collected in a horizontal Van Dorn bottle at a depth of $2 \mathrm{~m}$. Zooplankton were also collected by vertical tows using a net with $90 \mu \mathrm{m}$ mesh $(0.5 \mathrm{~m}$ in diameter and $2.5 \mathrm{~m}$ in length) equipped with a flowmeter. Temperature and salinity were measured at a depth of $2 \mathrm{~m}$ with a WTW LF 197 electronic multi-parametric sensor.

\subsection{Samples preparation}

In the laboratory, the particulate matter was collected by successively passing 101 of seawater through 90, 5 and $0.25 \mu \mathrm{m}$ pore Nytrel filters for phosphatase activity analysis. Additional filters were frozen at $-80{ }^{\circ} \mathrm{C}$ for protein determinations. Seawater was also passed on $0.25 \mu \mathrm{m}$ filters for orthophosphate and nitrate determinations.

\subsection{Abiotic parameters}

Orthophosphate concentrations were measured on the seawater filtrate as described by Murphy and Riley (1962) and nitrate as described by Wood, Armstrong, and Richards (1967) and modified by Le Poupon (1994).

\subsection{Biotic parameters}

Analysis of phytoplankton. A reverse filtration of the seawater was carried out to concentrate algal cells. They were preserved and stored in Lugol's reagent until examination. Large phytoplankton cells $(>5 \mu \mathrm{m})$ were identified and counted under 
an inverted Nikon Diaphot microscope according to the technique first described by Utermöhl (1958) and modified by Legendre and Watt (1971-1972) (total magnification $\times 400$ ). Owing to the presence of suspended matter, the identification of smaller cells was not carried out.

Analysis of zooplankton. Zooplankton samples collected with the net were stored in seawater-buffered 5\% formol. Aliquots for counts were taken with a Hensen pipette from the total sample adjusted to $250 \mathrm{ml}$.

Analysis of bacteria. The water sample was filtered on a black polycarbonate Nuclepore filter (mesh size $0.2 \mu \mathrm{m} ; 25 \mathrm{~mm}$ diameter). This membrane was covered with $1 \mathrm{ml}$ of DAPI solution $\left(50 \mu \mathrm{g} \mathrm{ml}^{-1}\right)$ and left to stain in the dark. The stained filters were observed in a dark room under an epifluorescence microscope (total magnification $\times 1000$ ) with immersion oil as described in Porter and Feig (1980).

Proteins. After re-suspension of the particulate matter in distilled water $(10 \mathrm{ml}$ per filter), the proteins from each size class were quantified by the Lowry technique (Lowry, Rosenbrough, Farr, \& Randall, 1951). Bovine serum albumin (BSA) was used as a standard. Proteins were measured in triplicate. The mean \pm standard deviation protein concentrations are presented.

Chlorophyll. Chlorophyll $a$ was analysed with visible spectrophotometry (acetone extract) according to Clesceri, Greenberg, and Eaton (1998).

\subsection{Phosphatase activities}

The phosphatase activities of the unfiltered seawater and of the particles retained on each filter were immediately determined. Paranitrophenylphosphate (pNPP) was used as substrate and 7-10 concentrations $(0.001-20 \mathrm{mM})$ were prepared for each experiment. Phosphatase activities were measured at $25^{\circ} \mathrm{C}$. The paranitrophenol (PNP) produced was followed by measuring absorbance at $410 \mathrm{~nm}$ (Jamet, Aleya, \& Devaux, 1995; Jean, Bogé, Jamet, Richard, \& Jamet, 2003; Reichardt, Overbeck, \& Steubing, 1967).

In seawater. Immediately after sampling, $\mathrm{pNPP}$ was dissolved in seawater ( $\mathrm{pH}$ 8.3) and the production of PNP was measured after $24 \mathrm{~h}$ at $25^{\circ} \mathrm{C}$.

In particulate matter. To mimic natural conditions as closely as possible, pNPP was dissolved in seawater ( $\mathrm{pH}$ 8.3). To prepare the enzyme suspension, the particulate matter retained on the filters was re-suspended at $2^{\circ}$ in $10 \mathrm{ml}$ pre-filtered $(0.25 \mu \mathrm{m}$ pore size $)$ seawater using a sonicator. Reactions started when the enzyme suspension was added to the substrate solution. The PNP concentration was followed for at least $1 \mathrm{~h}$. Blanks consisting of pre-filtered seawater were used to take into account the effect of the dissolved enzymes.

\subsection{Calculations}

The activities are expressed as Vmax (the reaction rate when the enzyme is saturated with substrate) and $\mathrm{Km}$ (the half saturation concentration). For the different size classes, specific activities were also calculated by the ratio between Vmax and protein concentrations of the particulate material. 
As two saturable components are generally involved in the phosphatase activity (Jean et al., 2003), Michaelis Menten curves were subjected to Eadie Hofstee transformations (Activity versus Activity/Substrate concentration). The "Table Curve" software was used to determine the kinetic parameters of each activity and the standard errors (SEM) of these constants. Examples of this analysis are presented in Fig. 4(a) and (b). The differences between the observed Eadie Hofstee curves and the curves based on the calculated constants are less than $4 \%$.

\subsection{Statistics}

The correlations between phosphatase activities and the biotic and abiotic parameters were carried out using the non-parametric Spearman correlation test.

\section{Results}

\subsection{Abiotic parameters}

Rain fall was very heavy in September, October and November 1999 and resulted in major changes in nutrient concentrations. Indeed, during this period, nitrate and phosphate concentrations were generally more elevated. Phosphate concentrations peaked also in February, June and above all in May whereas nitrate concentrations remained more stable from January to September. This rainfall also affected the salinity, which dropped from $38 \%$ to $29 \%$ in October (Table 1).

\subsection{Biotic parameters}

In Toulon Bay, the bacterial abundance varied from $1.24 \times 10^{5}$ cells ml $^{-1}$ in November to $7.88 \times 10^{5} \mathrm{cells} \mathrm{m}^{-1}$ in April, with an annual average of $3.37 \times 10^{5}$ cells ml ${ }^{-1}$. The succession of bacteria showed low levels in autumn and winter, and high levels in spring and early summer. In the second half of summer, bacterial abundance was low (Fig. 2).

The algal biomass, measured by chlorophyll $a$ concentration, peaked in February and was minimal in December and July (Fig. 2). The algal community was merely composed of Dinophyceae. Among the largest cells $(>5 \mu \mathrm{m})$ Alexandrium spp., Prorocentrum spp., Ceratium spp., Gymnodiniuim spp. and Protoperidinium spp. were the most abundant. Alexandrium spp. densities peaked in March $\left(2894 \mathrm{cell}^{-1}\right)$ and

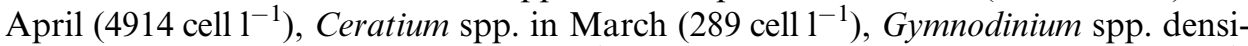
ties increased in February $\left(1318\right.$ cell $\left.1^{-1}\right)$, Protoperidium spp. in June $\left(374\right.$ cell $\left.1^{-1}\right)$ and Prorocentrum spp. in April (2432 cell $1^{-1}$ ) (Table 2).

The zooplankton community was dominated by copepods (larvae and adults) throughout the year. Copepods were mainly represented by cyclopoids (23-87\%). The abundance of adults peaked in February, whereas the densities of larvae increased in May and June (Fig. 3). 


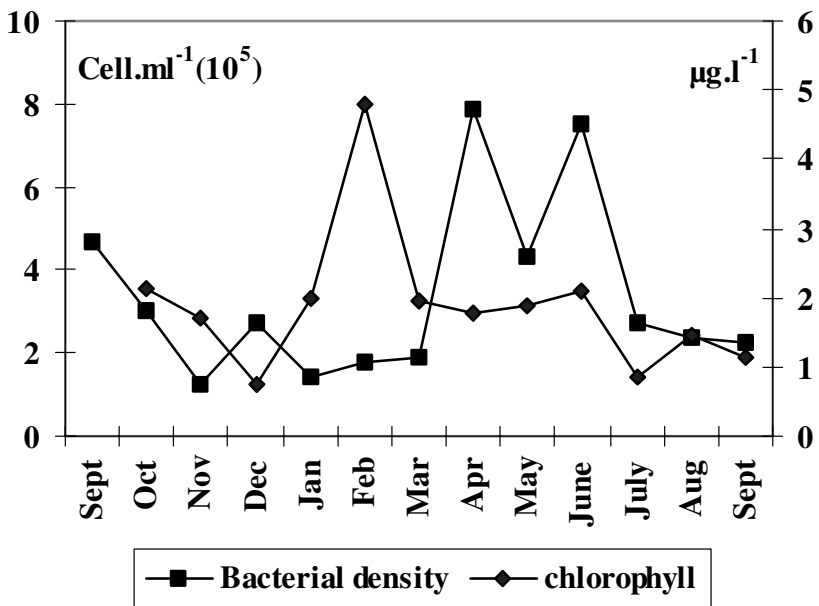

Fig. 2. Chlorophyll $a$ concentrations $\left(\mu \mathrm{g}^{-1}\right)$ and bacterial densities $\left(\times 10^{5}\right.$ bact. $\left.\mathrm{ml}^{-1}\right)$.

Table 2

Phytoplankton cell abundances (in cell $1^{-1}$ )

\begin{tabular}{lccccc}
\hline & Alexandrium & Ceratium & Gymnodinium & Protoperidinium & Prorocentrum \\
\hline September & 25 & 0 & 62 & 18 & 148 \\
October & 6 & 6 & 43 & 0 & 160 \\
November & 55 & 92 & 265 & 25 & 185 \\
December & 64 & 5 & 0 & 15 & 128 \\
January & 185 & 92 & 690 & 37 & 382 \\
February & 1392 & 74 & 1318 & 50 & 1921 \\
March & 2894 & 289 & 0 & 142 & 1970 \\
April & 4914 & 62 & 74 & 37 & 2432 \\
May & 1490 & 74 & 0 & 37 & 590 \\
June & 0 & 39 & 315 & 374 & 213 \\
July & 137 & 0 & 356 & 32 & 56 \\
August & 21 & 7 & 0 & 14 & 383 \\
September & 82 & 30 & 0 & 0 & \\
\hline
\end{tabular}

\subsection{Total seawater activity}

We measured the phosphatase activity of unfiltered seawater. As previously shown for the activity of the particulate matter (Gambin et al., 1999; Jean et al., 2003) the Eadie Hofstee curves were not linear. The analysis of these curves indicates that two Michaelian processes with low and high affinities were involved in the hydrolysis of phosphoric esters (Fig. 4(a) for annual mean values).

The low affinity activity (VI). Its $\mathrm{Km}(\mathrm{Km} 1)$ was between 3 and $15.2 \mathrm{mM}$ (Table 3). Its Vmax was low during the first three months of the study. Then it increased progressively from November to January and declined thereafter until 


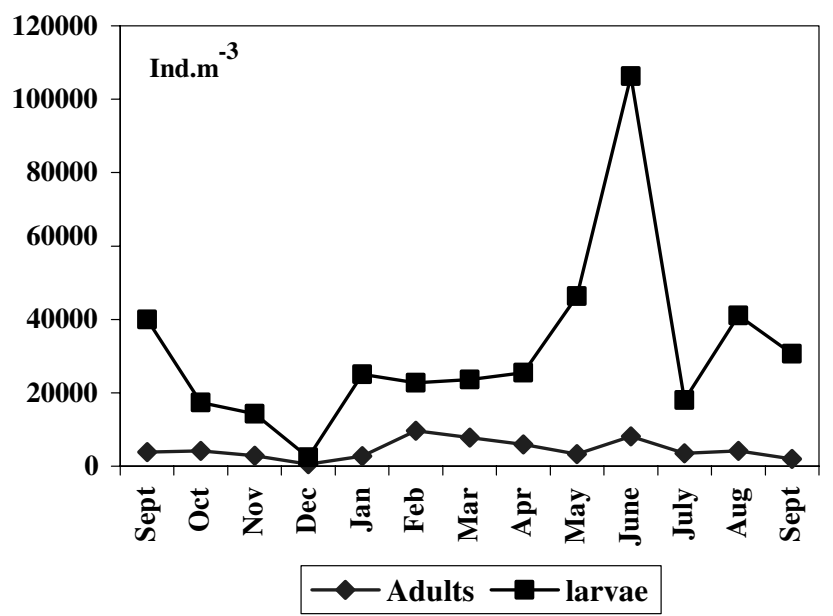

Fig. 3. Zooplankton abundances (adults and larvae, ind. $\mathrm{m}^{-3}$ ).

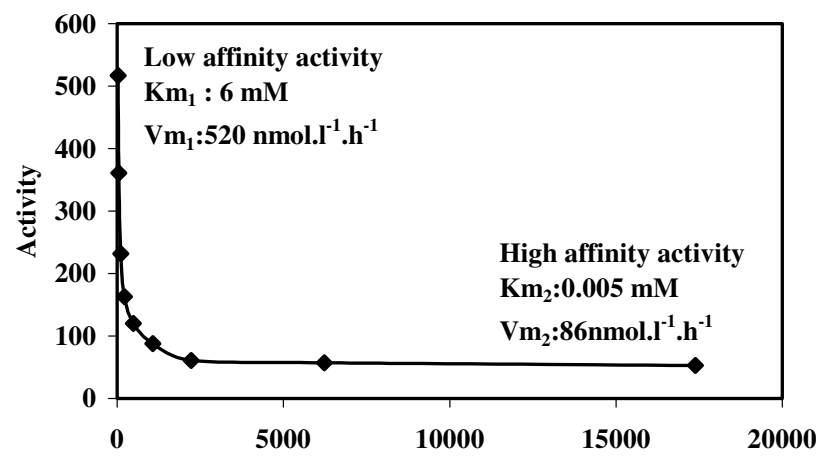

(a) Activity/Substrate concentration

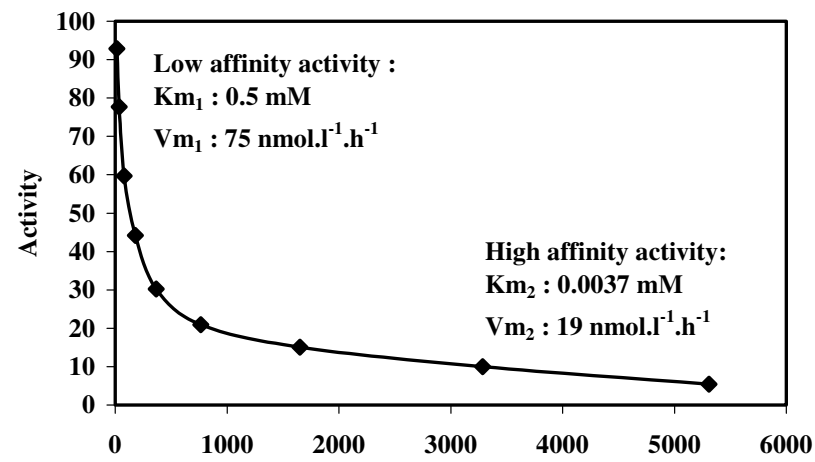

(b)

Activity/Substrate concentration

Fig. 4. Eadie Hofstee representation (Activity versus Activity/Substrate concentration) of the low and of the high affinity activities in unfiltered seawater (a) and in the total particulate material (b). 
Table 3

$\mathrm{Km}$ values (in $\mathrm{mM})$ of the low $(\mathrm{Km} 1)$ and of the high $(\mathrm{Km} 2)$ affinity phosphatase activities in unfiltered seawater (SEM: standard error)

\begin{tabular}{lll}
\hline & Km1 (SEM) & Km2 (SEM) \\
\hline September & $14.5(4.8)$ & $0.006(0.001)$ \\
October & $6.5(1.4)$ & $0.185(0.026)$ \\
November & 12.7 & 0.075 \\
December & $9.2(3.5)$ & $0.082(0.028)$ \\
January & $6(1.2)$ & Nd \\
February & $\mathrm{Nd}$ & $0.258(0.2)$ \\
March & 9.75 & $0.285(0.26)$ \\
April & $3(0.6)$ & $0.007(0.001)$ \\
May & $4.75(1)$ & $0.005(0.001)$ \\
June & $5.25(1.7)$ & $0.012(0.01)$ \\
July & $14(4)$ & $0.012(0.01)$ \\
August & $15.2(6.4)$ & $0.01(0.003)$ \\
September & 14.5 & 0.006 \\
\hline
\end{tabular}

March. Later on, monthly fluctuations occurred. High activities were also observed in April, June and August. In return, in September low activities were found (Fig. 5).

The high affinity activity (V2). Its $\mathrm{Km}(\mathrm{Km} 2)$ fluctuated from 0.005 to $0.285 \mathrm{mM}$ throughout the year (Table 3). Its Vmax values were generally lower than for the low affinity activity (Fig. 5). They remained very low from October to March. Higher levels were shown in April and June. They were significantly correlated $(p<0.05)$ with the bacterial density (Fig. 2).

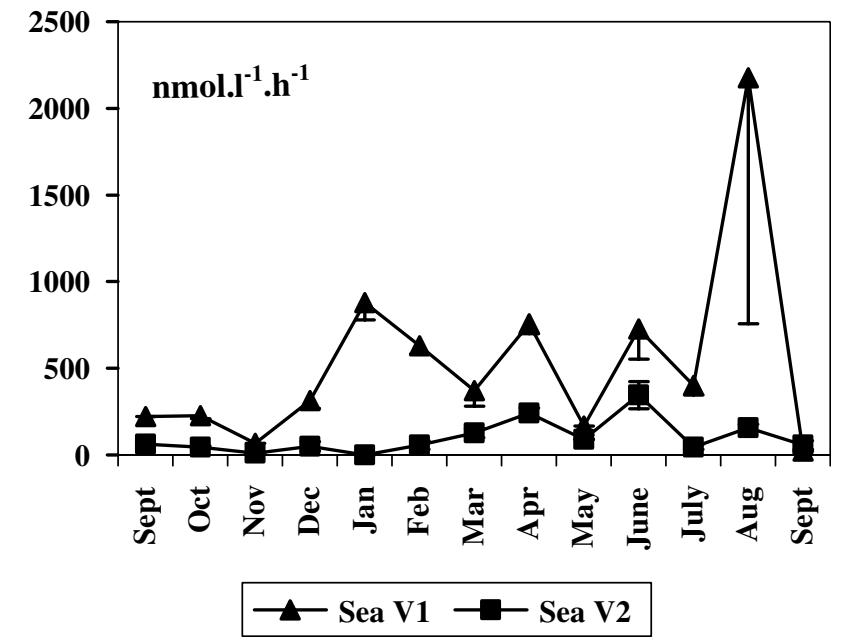

Fig. 5. Vmax of the low (V1) and of the high (V2) affinity phosphatase activities in unfiltered seawater $\left(\mathrm{nmol} \mathrm{l}^{-1} \mathrm{~h}^{-1}\right)$. 
The mean activities of these two components were more elevated from May to September (2000) than from September (1999) to April (2000) (V1: $698 \mathrm{nmol}^{-1} \mathrm{~h}^{-1}$ versus $433 \mathrm{nmol} \mathrm{l}^{-1} \mathrm{~h}^{-1}$; V2: $139 \mathrm{nmol}^{-1} \mathrm{~h}^{-1}$ versus $74 \mathrm{nmol}^{-1} \mathrm{~h}^{-1}$ ).

\subsection{Total particulate matter activity}

As for seawater, the total particulate activity (the sum of the three size class activities) had two components with low and high affinities. The annual means of $\mathrm{Km}$ and Vmax of each component are indicated in Fig. 4(b).

The low affinity activity (VI). Its Vmax values were low and showed marginal fluctuations from September to April. Then they increased in May, June and August (Fig. 6). But they rarely exceeded $10 \%$ of the total seawater low affinity activity, except in November, May and September when they reached more than $70 \%$ (data not shown).

The high affinity component (V2). Its Vmax values were low from October to January. They increased in February, June and August (Fig. 6). This activity was generally about $30 \%$ or more of the total seawater except in October, March and April when this contribution did not exceed $10 \%$ (data not shown).

For the two components, the mean activities were more elevated from May to September (2000) than from September (1999) to April (2000) (V1: $122 \mathrm{nmol} \mathrm{l}^{-1} \mathrm{~h}^{-1}$ versus $30 \mathrm{nmoll}^{-1} \mathrm{~h}^{-1}$; V2: $41 \mathrm{nmol}^{-1} \mathrm{~h}^{-1}$ versus $\left.18 \mathrm{nmol}^{-1} \mathrm{~h}^{-1}\right)$.

\subsection{The contribution of the $>90 \mathrm{~mm}$ size fraction}

The $\mathrm{Km}$ of the low affinity activity $(\mathrm{Km} 1)$ was between 0.05 and $10 \mathrm{mM}$ (Table 4). In December, May, June, July and August the $>90 \mu \mathrm{m}$ class contributed for more than $80 \%$ to the low affinity activity of the total particulate matter (Fig. 7(a)). Very

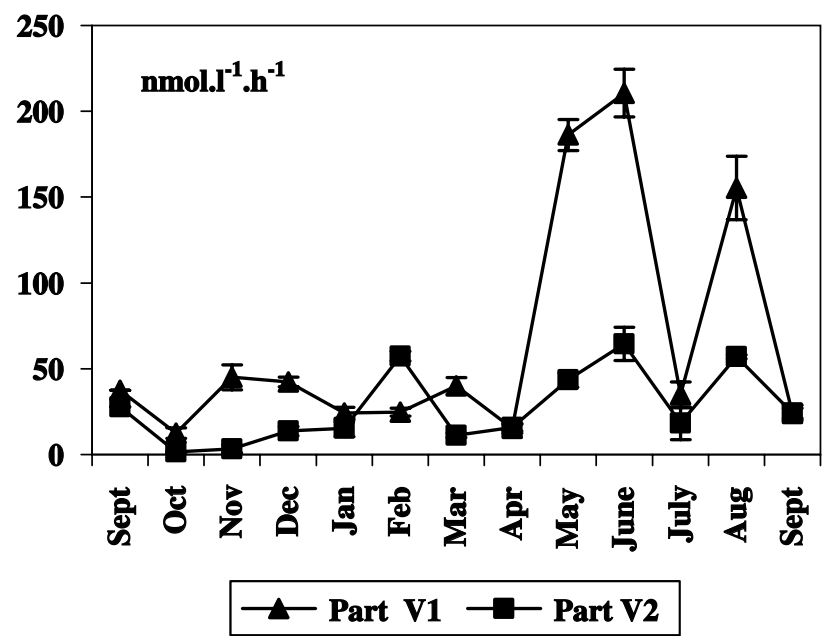

Fig. 6. Vmax of the low (V1) and of the high (V2) affinity phosphatase activities in the total particulate material $\left(\mathrm{nmol} \mathrm{l}^{-1} \mathrm{~h}^{-1}\right)$. 
Table 4

$\mathrm{Km}$ values (in $\mathrm{mM})$ of the low $(\mathrm{Km} 1)$ and of the high $(\mathrm{Km} 2)$ affinity phosphatase activities in the three size classes of the particulate material (SEM: standard error)

\begin{tabular}{|c|c|c|c|c|c|c|}
\hline \multirow[t]{2}{*}{ Fractions } & \multicolumn{2}{|l|}{$>90 \mu \mathrm{m}$} & \multicolumn{2}{|l|}{ 5-90 $\mu \mathrm{m}$} & \multicolumn{2}{|l|}{$0.25-5 \mu \mathrm{m}$} \\
\hline & Km1 (SEM) & $\mathrm{Km} 2$ (SEM) & $\mathrm{Km} 1$ (SEM) & $\mathrm{Km} 2$ (SEM) & Km1 (SEM) & $\overline{\mathrm{Km} 2 \text { (SEM) }}$ \\
\hline September & $1(0.181)$ & $0.12(0.1)$ & 10 & $0.025(0.157)$ & 17 & $0.104(0.095)$ \\
\hline October & $1.5(0.565)$ & $0.03(0.003)$ & $1(0.244)$ & 0.015 & $0.5(0.379)$ & $0.03(0.005)$ \\
\hline November & $1(0.12)$ & 0.005 & $1.5(0.902)$ & $0.007(0.004)$ & $2(0.394)$ & $0.002(0.002)$ \\
\hline December & $0.5(0.4)$ & $0.002(0.001)$ & $1.6(0.143)$ & 0.007 & $3(3)$ & $0.001(0.001)$ \\
\hline January & $1(0.12)$ & $0.012(0.001)$ & $1.6(0.086)$ & 0.023 & $2.5(0.569)$ & 0.007 \\
\hline February & $1.7(0.584)$ & $0.025(0.006)$ & $2(0.438)$ & $0.011(0.001)$ & $1.5(0.235)$ & $0.006(0.001)$ \\
\hline March & 10 & $0.021(0.016)$ & $2(0.472)$ & $0.005(0.004)$ & $4(0.19)$ & 0.027 \\
\hline April & 7.5 (1.17) & $0.008(0.003)$ & $1(0.618)$ & $0.003(0.001)$ & 10 & $0.006(0.002)$ \\
\hline May & $0.5(0.05)$ & 0.135 & $1(0.216)$ & $0.004(0.001)$ & $0.5(0.082)$ & $0.002(0.001)$ \\
\hline June & $0.5(0.05)$ & 0.127 & 19.5 & $0.022(0.017)$ & $19.5(1.1)$ & $0.005(0.004)$ \\
\hline July & $0.5(0.262)$ & $0.012(0.001)$ & $5.5(7.4)$ & $0.002(0.001)$ & $\mathrm{Nd}$ & $0.007(0.007)$ \\
\hline August & $0.5(0.282)$ & $\mathrm{Nd}$ & 0.5 & $0.004(0.004)$ & 1 & $0.009(0.005)$ \\
\hline September & $0.5(0.103)$ & 0.017 & 0.5 & 0.003 & 0.5 & $0.003(0.001)$ \\
\hline
\end{tabular}

Nd: not determined.

high Vmax and specific activities were then observed notably in June and August (Fig. 8(a) and Table 5). In counterpart, the contribution of this size class was very low in October, November and March $(<10 \%)$.

The $\mathrm{Km}$ of the high affinity activity $(\mathrm{Km} 2)$ was between 0.002 and $0.135 \mathrm{mM}$ (Table 4). The contribution of this size class to the total high affinity activity was generally lower than for the low affinity activity in particular from May to September 2000 (Fig. 7(b)). During the annual cycle, the Vmax values increased in December, February, May, July and August and the specific activities in September, December, May and above all in August (Fig. 8(b) and Table 5).

No correlation existed between these activities and the abundance of adult copepods, whereas a significant correlation $(p<0.05)$ was found between the low affinity activity and the larvae (copepodites) abundances (Fig. 3).

\subsection{The contribution of the 5-90 $\mathrm{mm}$ size fraction}

The low affinity component had $\mathrm{Km}$ values $(\mathrm{Km} 1)$ ranging between 0.5 and $19.5 \mathrm{mM}$, whereas for the high affinity component they were between 0.002 and $0.025 \mathrm{mM}$ (Table 4). Between September and April, the low affinity activity (V1) had a major contribution to the total activity of the particulate material. Indeed, except in December, it represented between 30\% and 80\% (annual mean: 38\%) of the particulate matter activity (Fig. 7(a)). This contribution was more important in November and March when high specific activities and Vmax were observed. High specific low affinity activities were also detected in June and August. Moreover high Vmax were found in May (Table 5 and Fig. 8(a)).

The contribution of the high affinity activity ranged between $40 \%$ and $90 \%$ of the total particulate activity (annual mean: $51 \%$, Fig. 7(b)), the highest values being 


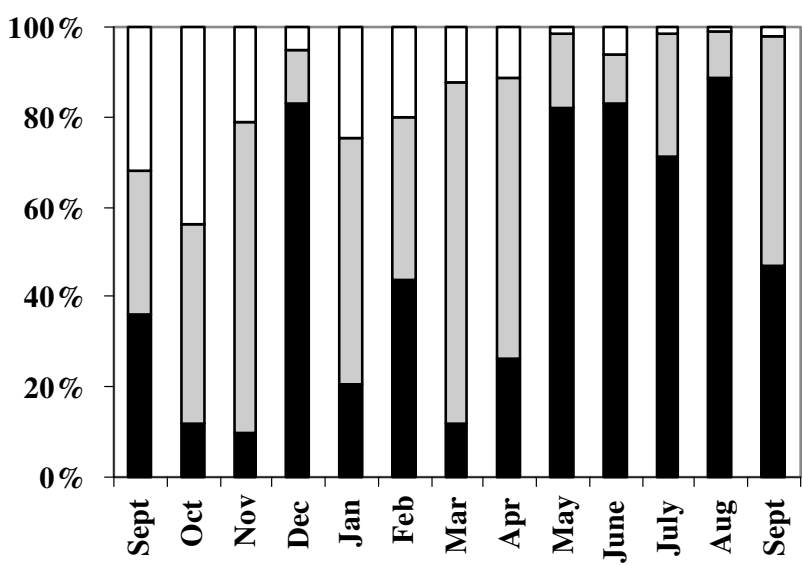

(a)

$\square>90 \mu \square 5-90 \mu \square 0.25-5 \mu$

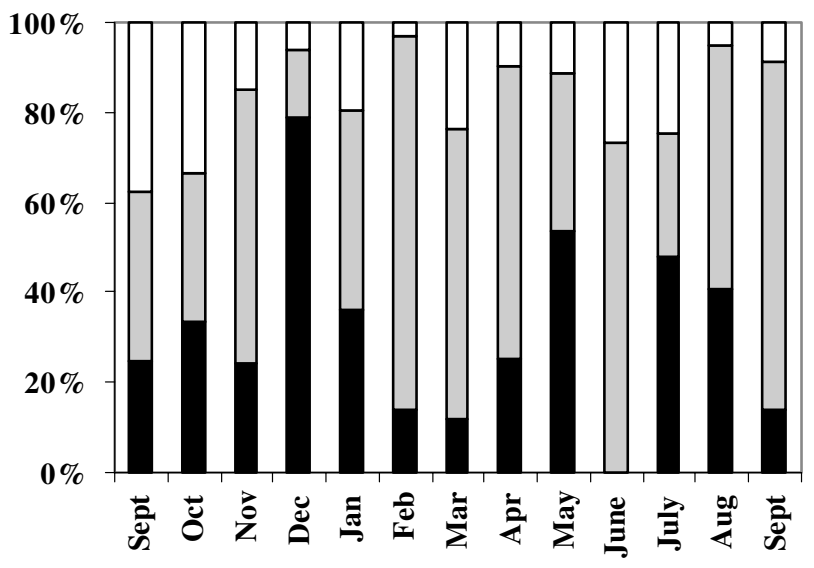

(b)

$\square>90 \mu \square 5-90 \mu \square 0.25-5 \mu$

Fig. 7. Contribution in per cent of the three size classes to the low (a) and high (b) affinity phosphatase activities of the particulate material.

observed in February, June and September when the Vmax and the specific activities were elevated. These activities increased also in August whereas they remained particularly low from October to January (Fig. 8(b) and Table 5).

The enzyme activities were not correlated with chlorophyll or cell abundance but showed relationships with specific Dinoflagellates. So, the high activities of the low affinity component in November and March were observed when the densities of Ceratium spp. increased ( 92 cell $1^{-1}$ in November and 289 cell $1^{-1}$ in March). The high activity of the high affinity component in February and June increased together 


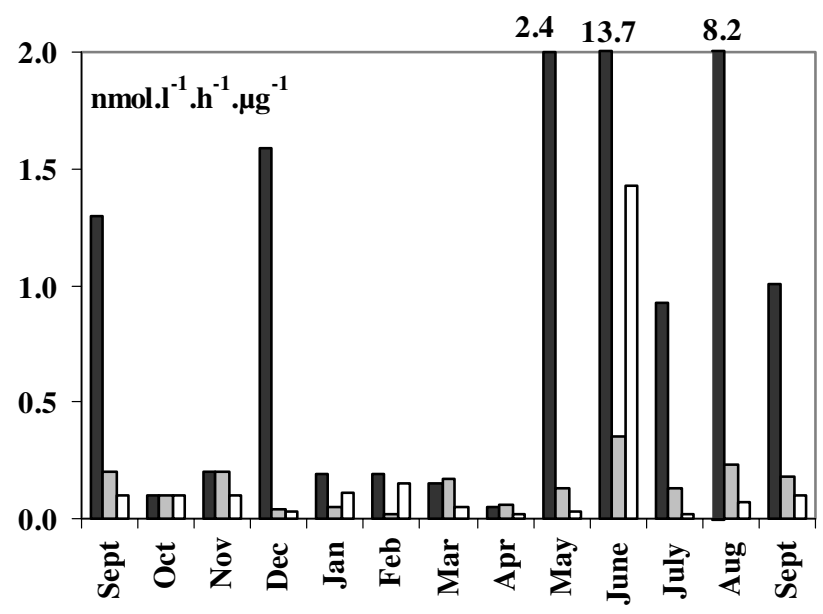

(a)

$\square 90 \mu \square 5-90 \mu \square 0.25-5 \mu$

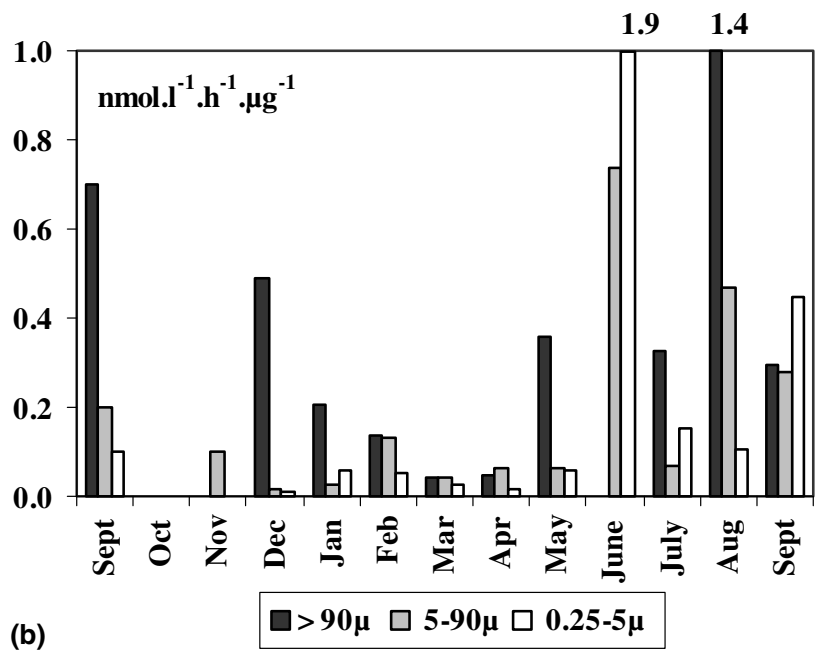

Fig. 8. The specific activity of the low (a) and of the high (b) affinity phosphatase activities in the three size classes $\left(\mathrm{nmol} 1^{-1} \mathrm{~h}^{-1} \mu \mathrm{g}^{-1}\right)$.

with the abundances of Gymnodinium spp. $\left(1318\right.$ cell $\left.^{-1}\right)$ and Protoperidinium spp. $\left(374\right.$ cell $\left.1^{-1}\right)$ (Table 2$)$.

\subsection{The contribution of the $0.25-5 \mathrm{~mm}$ size fraction}

Activities with distinct affinities were also observed for this fraction. Km fluctuated between 0.5 and $19.5 \mathrm{mM}$ for the low affinity activity $(\mathrm{Km} 1)$ and between 0.001 and $0.104 \mathrm{mM}(\mathrm{Km} 2)$ for the high affinity activity (Table 4). The contribution 
Table 5

Vmax of the low $(\mathrm{Vm} 1)$ and of the high $(\mathrm{Vm} 2)$ affinity phosphatase activities in the three size classes of the particulate material $\left(\mathrm{nmol}^{-1} \mathrm{~h}^{-1}\right)$ (SEM: standard error)

\begin{tabular}{|c|c|c|c|c|c|c|}
\hline \multirow[t]{2}{*}{ Fractions } & \multicolumn{2}{|l|}{$>90 \mu \mathrm{m}$} & \multicolumn{2}{|l|}{$5-90 \mu \mathrm{m}$} & \multicolumn{2}{|l|}{$0.25 \mu \mathrm{m}$} \\
\hline & $\mathrm{Vm} 1$ (SEM) & $\mathrm{Vm} 2(\mathrm{SEM})$ & $\mathrm{Vm} 1$ (SEM) & $\mathrm{Vm} 2(\mathrm{SEM})$ & $\mathrm{Vm} 1$ (SEM) & $\overline{V m} 2$ (SEM) \\
\hline September & 13.5 & 6.9 & 12.0 & 10.5 & 12.0 & 10.5 \\
\hline October & $1.5(0.26)$ & $0.5(0.06)$ & $5.5(1.4)$ & $0.5(0.2)$ & $5.5(1.4)$ & $0.5(0.23)$ \\
\hline November & $4.5(0.46)$ & $0.8(0.8)$ & $31(4.5)$ & $2(1.41)$ & $9.5(2.2)$ & $0.5(0.01)$ \\
\hline December & $35(1.81)$ & $10.8(2.1)$ & $5(0.46)$ & $2(0.43)$ & $2.25(0.5)$ & $0.85(0.13)$ \\
\hline January & $5(0.44)$ & $5.5(4.1)$ & $13.3(2.1)$ & $6.75(0.16)$ & $6(0.6)$ & $3(0.51)$ \\
\hline February & $10.8(0.8)$ & $7.83(1.3)$ & $8.83(1)$ & 47.8 (1.4) & $5(0.5)$ & $1.67(0.11)$ \\
\hline March & $4.83(0.94)$ & $1.33(0.3)$ & $30.2(2.3)$ & $7.17(0.83)$ & $5(1.6)$ & $2.67(0.18)$ \\
\hline April & $4(1)$ & $4(0.6)$ & $9.5(1.2)$ & $10.2(0.9)$ & $1.75(0.5)$ & $1.5(0.47)$ \\
\hline May & $153(6.5)$ & 23.3 & $30.2(2.4)$ & $15.2(3.62)$ & $3(0.23)$ & $5(0.65)$ \\
\hline June & 175.0 & 0.0 & $22.8(9.3)$ & $47.3(3.7)$ & $12.8(4.5)$ & $17.2(6)$ \\
\hline July & $24.8(4.3)$ & 8.75 (4.7) & $9.5(1.4)$ & $5(1.8)$ & 0.5 & $4.5(3.1)$ \\
\hline August & $138(15.9)$ & 23.3 & $15.5(2.1)$ & $30.8(0.5)$ & $1.83(0.4)$ & $2.93(0.7)$ \\
\hline September & $11.3(2.2)$ & $3.33(2.3)$ & $12.2(0.7)$ & $18.8(1.5)$ & 0.5 & $2.2(0.63)$ \\
\hline
\end{tabular}

of these activities to the total particulate activities rarely exceeded 20\% (Fig. 7(a) and (b)). The Vmax and the specific activities were also generally low except in June and September 1999 (Table 5, Fig. 8(a) and (b)).

For the three size classes, the specific activities were always more elevated from May to September (2000) than from September (1999) to April (2000), especially for the high affinity component (for the $>90 \mu \mathrm{m}$ size class: $0.5 \mathrm{nmol}^{-1} \mathrm{~h}^{-1} \mu \mathrm{g}^{-1}$ against $0.2 \mathrm{nmol}^{-1} \mathrm{~h}^{-1} \mu \mathrm{g}^{-1}$; for the 5-90 $\mu \mathrm{m}$ size class: $0.3 \mathrm{nmol}^{-1} \mathrm{~h}^{-1} \mu \mathrm{g}^{-1}$ against $0.1 \mathrm{nmol}^{-1} \mathrm{~h}^{-1} \mu \mathrm{g}^{-1}$; for the $0.25-5 \mu \mathrm{m}$ size class: $0.5 \mathrm{nmol}^{-1} \mathrm{~h}^{-1} \mu \mathrm{g}^{-1}$ against $\left.0.03 \mathrm{nmol} \mathrm{l}^{-1} \mathrm{~h}^{-1} \mu \mathrm{g}^{-1}\right)$.

\section{Discussion}

The use of a broad range of substrate concentrations $(0.001-20 \mathrm{mM})$ confirmed that in seawater and in particulate material, the hydrolysis of organic phosphorus monoesters was supported by high and low affinity activities (Jean et al., 2003). Alkaline phosphatases have broad substrate specificity and high substrate affinity (Hoppe, 2003). The low $\mathrm{Km}$ of the high affinity activity makes it more effective in natural conditions where the substrate concentrations were generally micromolar or less (Benitez-Nelson, 2000). However, despite its high $\mathrm{Km}$, the low affinity activity may also play a role because of its high Vmax.

The seawater activity comes from dissolved enzymes and/or from activities associated with living and dead particles (Jansson et al., 1988). In this work, the particulate activity was the sum of internal and external activities. It remains much lower than the total seawater activity. Indeed the mean ratio between the particulate and the total activities was approximately 0.14 for the low affinity component and 0.22 for the high affinity activity (calculated from the Vmax of Fig. 4(a) and (b)). This 
suggests that almost $80 \%$ of the total seawater activity originate from soluble enzymes. This soluble fraction derived from excreted enzymes or from intracellular enzymes transferred into seawater after the death of the cells or during stress situations (Jansson et al., 1988; Martinez \& Azam, 1993; Martinez, Smith, Stewart, \& Azam, 1996). In addition, it may originate from benthic algae which have notable phosphatase activities (Hernandez, Niell, \& Whitton, 2002).

In this work, we analysed the contribution of three different plankton size classes to the particle and seawater activities. Very high particulate low affinity activities were observed in May, June and August for the $>90 \mu \mathrm{m}$ fraction. This size class was in major part composed of zooplankton (adults and larvae). The significant correlation between this activity and copepodite abundance indicates that larvae played a major contribution to these activities. We previously showed that Cirriped larvae also exhibit high phosphatase activities which were not due to attached bacteria (Bogé, Richard, \& De Souza, 2004; Jean et al., 2003). Zooplankton, and notably Cirriped larvae (Bogé et al., 2004) has no extracellular phosphatase activity comparable to bacteria and phytoplankton. Its activity is intracellular and may contribute to the high activities of the unfiltered seawater in June and August after the death of the cells.

The 5-90 $\mu \mathrm{m}$ fraction also exhibits phosphatase activity. This size class contains phytoplankton which actively produce extracellular phosphatase (Hoppe, 2003; Jansson et al., 1988). In Toulon Bay, the contribution of phytoplankton to the total seawater activity was probably high from January to March when algal growth was strong. During this period, phytoplankton made also a marked contribution to the particulate activity which represented over $50 \%$ of the total particulate activity. This activity was not correlated with chlorophyll or cell abundance. In return, it showed relationships with specific genus and in particular with Ceratium spp. and Gymniodinium spp. The contribution of phytoplankton to water and particulate activity was also considerable in June and August, when cell abundance was markedly lower. This period was characterised by enhanced specific activities, which may originate from specific taxa and notably from Protoperidinium spp. Its abundance increased together with the activities of the high affinity component. During this period, the unfiltered seawater activity was also high, suggesting that a major part of the cell activity was secreted into the medium, liberated after cell death or active on cell walls.

In Toulon Bay, the contribution of the $0.25-5 \mu \mathrm{m}$ size class to the particulate activity rarely exceeds $20 \%$ of the total activity. Huang and Hong (1999) reported that in coastal waters, they were not the main carrier of the particulate alkaline phosphatase activity, which came from algae. Bacteria are known to express phosphatase activity which can be repressed by orthophosphate (Hoppe, 2003; Jansson et al., 1988). In Toulon bay, it is unlikely that the low activity of the $0.25-5 \mu \mathrm{m}$ size class results from such an inhibition as the seawater concentrations of dissolved inorganic phosphate were generally low with regard to the substrate concentrations used. It probably results from the $\mathrm{pH}$ of the experiments. They were carried out in seawater at $\mathrm{pH} 8.3$ which is far from the optimal $\mathrm{pH}$ of the bacterial phosphatases (9.5) but which is close to the optimum of the zooplankton activity (8.3) (Gambin et al., 1999). 
Conversely, in Toulon Bay, bacteria seem to make an important contribution to the seawater activity. Indeed, the high affinity activity of the unfiltered seawater was significantly correlated with bacterial density (see Section 3). In bacteria, phosphatase is generally located in the periplasmic space and excretion from living cells seems to be less common than in algae (Jansson et al., 1988). However, recent studies have shown that enzymes in the periplasmic space tend to occur in the free dissolved state (Hoppe, 2003). Huang and Hong (1999) also reported a possible link between bacteria and soluble phosphatase.

The phosphatase activities and the cell abundances were at their lowest level between September and December 1999. During this period strong rainfall occurred in Toulon Bay, resulting in increased nitrogen and phosphorus concentrations. In plankton species, the alkaline phosphatase activity is regulated by cellular $\mathrm{P}$ and $\mathrm{N}$ contents (Hoppe, 2003; Nausch, 2000; Petterson, 1980; Rengefors et al., 2003; Sakshaug, Graneli, Elbrächter, \& Kayser, 1984). But the decrease of the salinity, which probably caused the death of many algal cells, may also explain the low level of these activities. We also showed that these activities were generally more elevated from May to September (2000) than from September (1999) to April, and notably the high affinity component. This is also the case for the specific activities of the different size fractions. These observations suggest that at the end of spring, orthophosphate became more limiting for plankton and that high phosphatase activities were necessary to hydrolyse dissolved or particulate organic material.

\section{References}

Ammerman, J. W., \& Azam, F. (1991). Bacterial 5' nucleotidase activity in estuarine and coastal marine waters: Characterization of enzyme activity. Limnology and Oceanography, 36, 1427-1436.

Barth, H., \& Fegan, L. (1990). Eutrophication related phenomena in the Adriatic Sea and in other Mediterranean coastal zones (report no. 16). Water Pollution Research Report Series of the Environmental Programme of the Commission of the European Communities, Directorate General for Science, Research and Development.

Belin, C., \& Raffin, B. (1998). Les espèces phytoplanctoniques toxiques et nuisibles sur le littoral français de 1984 à 1995, résultats du REPHY (réseau de surveillance du phytoplancton et des phycotoxines). Rapport Ifremer Environnement, Décembre 1998, RST.DEL MP-AO 98-16.

Benitez-Nelson, C. R. (2000). The biogeochemical cycling of phosphorus in marine systems. Earth-Science Reviews, 51, 135-190.

Bethoux, J. P., \& Copin-Montegut, G. (1988). Phosphorus and nitrogen in the Mediterranean Sea: Specificities and forecasting. In: H. J. Minas, P. Nival (Eds.), Oceanologica Acta nESP, Océanographie pélagique méditerranéenne, pp. 75-78.

Bogé, G., Richard, S., \& De Souza, L. (2004). Characterization of a high phosphatasic activity in cirriped larvae. Rapp. Comm. int. Mer Médit., 37, 494.

Boon, P. I. (1994). Discrimination of algal and bacterial alkaline phosphatases with a differential inhibition technique. Australian Journal of Marine and Freshwater Research, 45, 83.

Clesceri, L. S., Greenberg, A. E., \& Eaton, A. D. (1998). Standard methods for the examination of water and wastewater. Prepared and published by American Public Health Association, American Water Works Association and Water Environment Federation.

Gambin, F., Bogé, G., \& Jamet, D. (1999). Alkaline phosphatase in a littoral Mediterranean marine ecosystem: Role of the main plankton size classes. Marine Environmental Research, 47, 441-456. 
Hernandez, I., Niell, F. X., \& Whitton, B. A. (2002). Phosphatase activity of benthic marine algae: An overview. Journal of Applied Phycology, 14, 475-487.

Hoppe, H. G. (2003). Phosphatase activity in the sea. Hydrobiologia, 493, 187-200.

Huang, B., \& Hong, H. (1999). Alkaline phosphatase activity and utilisation of dissolved organic phosphorus by algae in subtropical coastal waters. Marine Pollution Bulletin, 39, 205-211.

IFREMER. (1993). Qualité du milieu marin littoral. IFREMER et Ministère de l'enseignement supérieur et de la recherche, Ministère de l'agriculture et de la pêche, Ministère de l'environnement, p. 241.

Jamet, D., Aleya, L., \& Devaux, J. (1995). Diel changes in the alkaline phosphatase activity of bacteria and phytoplankton in the hypereutrophic Villerest reservoir (Roanne, France). Hydrobiologia, 300/301, 49-56.

Jamet, J. L., Bogé, G., Richard, S., Geneys, C., \& Jamet, D. (2001). The zooplankton community in bays of Toulon area (northwest Mediterranean Sea, France). Hydrobiologia, 457, 155-165.

Jansson, M., Olsson, H., \& Pettersson, K. (1988). Phosphatases: Origin, characteristics and function in lakes. Hydrobiologia, 170, 157-175.

Jean, N., Bogé, G., Jamet, J. L., Richard, S., \& Jamet, D. (2003). Seasonal changes in zooplanktonic alkaline phosphatase activity in Toulon Bay (France): The role of Cypris larvae. Marine Pollution Bulletin, 46, 346-352.

Legendre, L., \& Watt, W. D. (1971-1972). On a rapid technique for plankton numeration. Annales de $l$ Institut Oceanographique, Paris, 58, 173-177.

Le Poupon, C. (1994). Automatisation d'un procédé d'analyse de l'azote organique dissous après minéralisation en conditions réductrices. Thèse de Doctorat de l'Université de Toulon et du Var, 182 pp.

Lowry, O. H., Rosenbrough, N. J., Farr, A. L., \& Randall, R. J. (1951). Protein measurement with folin phenol reagent. Journal of Biological Chemistry, 193, 265-275.

Martinez, J., \& Azam, F. (1993). Periplasmic aminopeptidase and alkaline phosphatase activities in a marine bacterium in the sea. Marine Ecology-Progress Series, 92, 89-97.

Martinez, J., Smith, D. C., Stewart, G. F., \& Azam, F. (1996). Variability in ectohydrolytic enzyme activities of pelagic marine bacteria and its significance for substrate processing in the sea. Aquatic Microbial Ecology, 10, 223-230.

Murphy, J., \& Riley, J. P. (1962). A modified single solution method for the determination of phosphate in natural waters. An. Chem. Acta, 27, 31-36.

Nausch, M. (2000). Experimental evidences for interactions between bacterial peptidase and alkaline phosphatase activity in the Baltic Sea. Aquatic Ecology, 34, 331-343.

Petterson, K. (1980). Alkaline phosphatase activity and algal surplus phosphorus as phosphorus deficiency indicators in Lake Erken. Archiv fur Hydrobiologie, 89, 54-87.

Porter, K. J., \& Feig, Y. S. (1980). The use of DAPI for identifying and counting aquatic microflora. Limnology and Oceanography, 25, 943-948.

Reichardt, W. J., Overbeck, J., \& Steubing, L. (1967). Free dissolved enzymes in lake waters. Nature, 216, $1345-1347$.

Rengefors, K., Ruttenberg, K. C., Haupert, C. L., Taylor, C., Howes, B. L., \& Anderson, D. M. (2003). Experimental investigation of taxon-specific response of alkaline phosphatase activity in natural fresh water phytoplankton. Limnology and Oceanography, 48(3), 1167-1175.

Richard, S., \& Jamet, J. L. (2001). An unusual distribution of Oithona nana GIESBRECHT (1982) (Crustacea : Cyclopoida) in a bay: The case of Toulon Bay (France, Mediterranean Sea). Journal of Coastal Research, 17, 957-963.

Sakshaug, E. E., Graneli, M., Elbrächter, M., \& Kayser, H. (1984). Chemical composition and alkaline phosphatase activity of nutrient-saturated and P-deficient cells of four marine dinoflagellates. Journal of Experimental Marine Biology and Ecology, 77, 241-254.

Siuda, W. (1984). Phosphatases and their role in organic phosphorus transformation in natural waters. A review. Pol.Arch.Hydrobiol., 31, 207-233.

Thingstad, T. F., Zweifel, U. L., \& Rassoulzadegan, F. (1998). P limitation of heterotrophic bacteria and phytoplankton in the northwest Mediterranean. Limnology and Oceanography, 43, 1-88. 
Utermöhl, H. (1958). Zur Vervollkommung der quantitativen Phytoplankton - Methodik. Mitteilungen, Internationale Vereinigung fuer Theoretische und Angewandte Limnologie, 9, 1-38.

Wood, E. D., Armstrong, A. A. J., \& Richards, F. A. (1967). Determination of nitrate in sea water by cadmium-copper reduction to nitrite. Journal of the Marine Biological Association of the United Kingdom, 47, 23-31. 